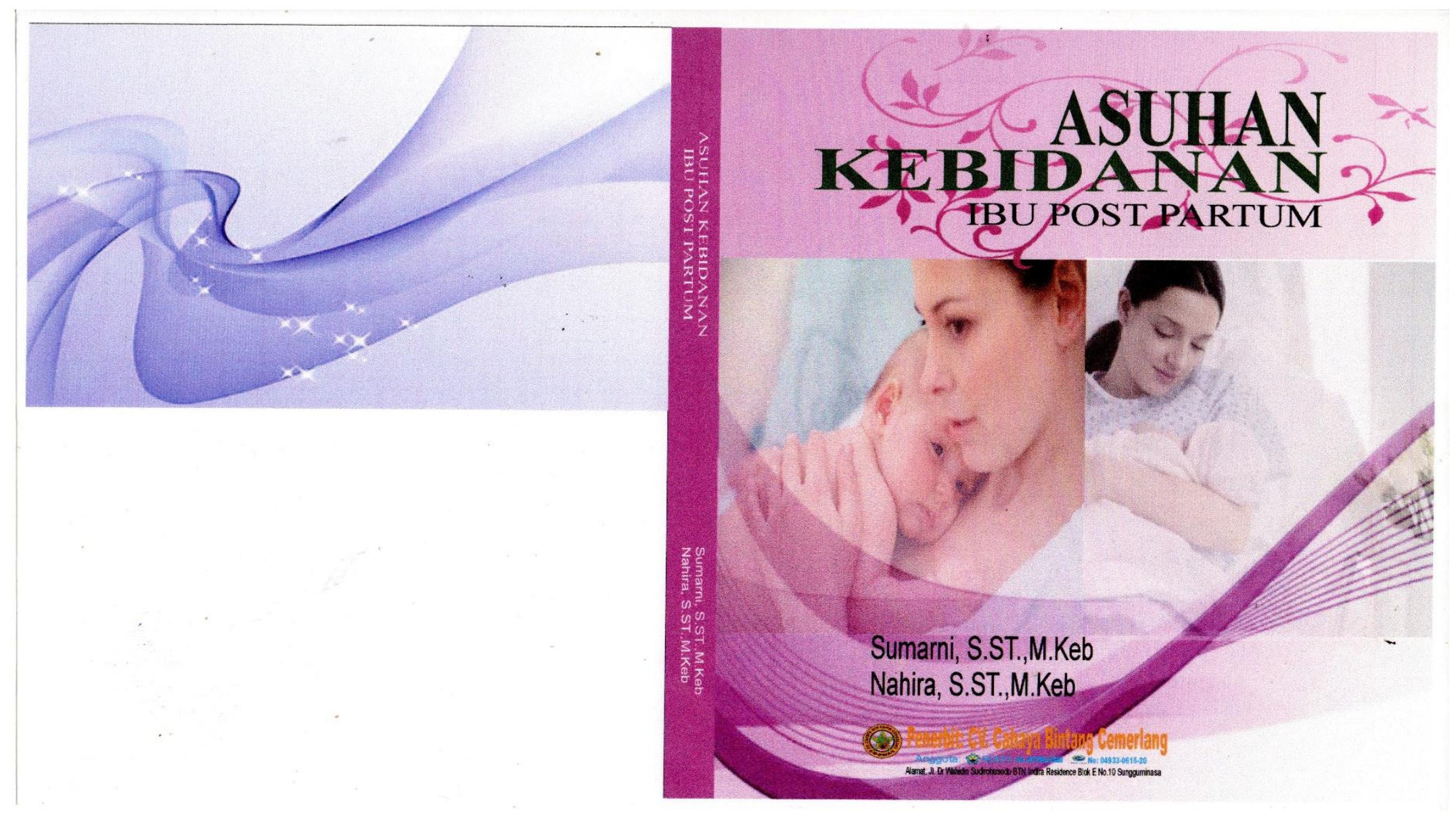




\section{Penulis}

SUMARNI, S.ST., M. Keb

NAHIRA, S.ST., M.Kes

Penerbit: CV. Cahaya Bintang Cemerlang 


\title{
ASUHAN KEBIDANAN IBU POST PARTUM
}

\author{
Penulis: \\ SUMARNI, S.ST., M.Keb \\ NAHIRA, S.ST.,M.Keb \\ ISBN: 978-623-6032-19-0 \\ Editor : \\ FADJRIAH OHORELLA, S.ST., M.Kes., M.Keb \\ Penyunting: \\ Harmawati, S.Sos \\ Desain Sampul dan Tata Letak
}

Muh Yunus Nabbi

Penerbit:

CV. CAHAYA BINTANG CEMERLANG

Redaksi :

J1. Dr. Wahidin Sudirohusodo BTN Indira Residence Blok E No. 10

Sungguminasa Kab. Gowa

Email : muhyunusnabbi@gmail.com

Distributor Tunggal

Penerbit CV. CAHAYA BINTANG CEMERLANG

J1. Dr. Wahidin Sudirohusodo BTN Indira Residence Blok E No. 10

Sungguminasa Kab. Gowa

No. HP: 085256649684 /

085290480054

Email : muhyunusnabbi@gmail.com

Cetakan Pertama, September 2019

Hak cipta dilindungi Undang-undang

Dilarang memperbanyak karya tulis ini dalam bentuk dan dengan caraApapun tanpa ijin tertulis dari Penerbit. 


\section{KATA PENGANTAR}

Alhamdulillah Dengan mengucapkan Syukur atas Kehadirat ALLAH SWT atas segala Rahmat dalam memberikan kekuatan dan kesempatan sehingga buku yang berjudul “ASUHAN KEBIDANAN IBU POST PARTUM".

Tak lupa pula dalam penyusunan buku ini tidak terlepas dari berbagai pihak yang membantu memberikan doa dan cinta dari kedua orang tua, suami dan anakku Muh. Aqil Sahid Mahya dan Muh. Fadhil Algazali serta saudara saudariku yang sangat amat kucintai, serta rekan rekan sekantor yang banyak memberikan motivasi

Seperti lazimnya sebuah buku, tidak terlepas dari ketidak lengkapan isi, demikian juga dengan buku ini. Namun, terlepas dari segala kekurangan yang ada. Semoga buku ini dapat memberikan manfaat kepada yang membacanya . Terimakasih 


\section{DAFTARA ISI}

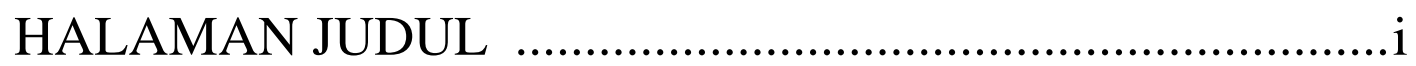

HALAMAN REDAKSI PENERBIT.......................................ii

PENGANTAR ................................................................

DAFTAR ISI ......................................................................

BAB I KONSEP DASAR MASA NIFAS

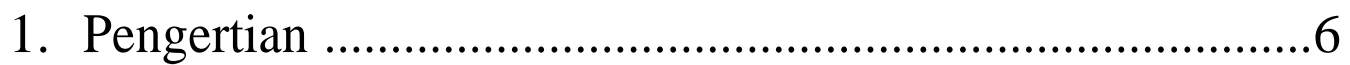

2. Tahapan Masa Nifas ....................................................6

BAB II PERUBAHAN FISIOLOGIS MASA NIFAS

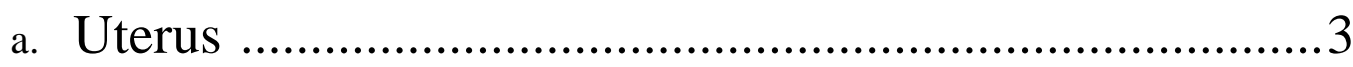

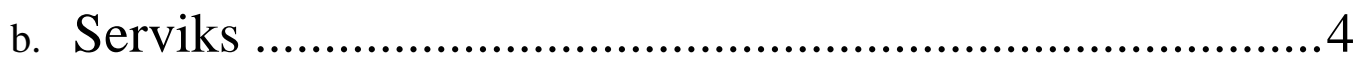

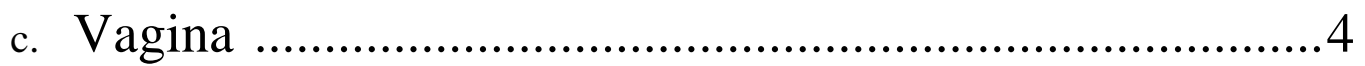

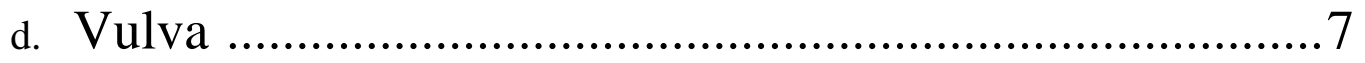

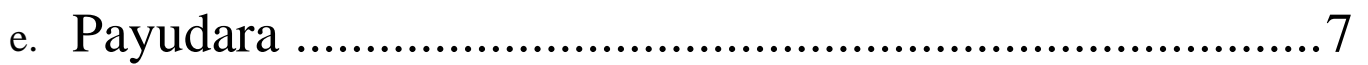
f. Tanda - tanda Vital .................................................. 7
g. Sistem Peredaran Darah ................................................. 8

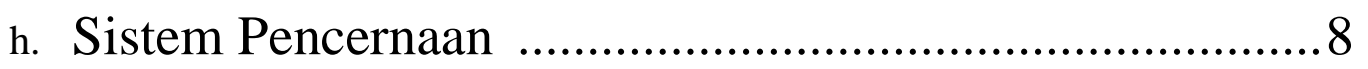
i. Sistem Perkemihan ........................................................ 9
j. Sistem integument............................................................ 9
k. Sistem Muscloskletal ......................................................10

\section{BAB III PERUBAHAN PSIKOLOGIS MASA NIFAS}

a. Adaptasi psikologi ibu dalam masa nifas...........................11

b. Postpartum blue (Beby Blue)............................................13

c. Depresi postpartum ..........................................................14

d. Raspon antara ibu dan bayi setelah persalinan ................14

\section{BAB IV KEBUTUHAN DASAR IBU MASA NIFAS}

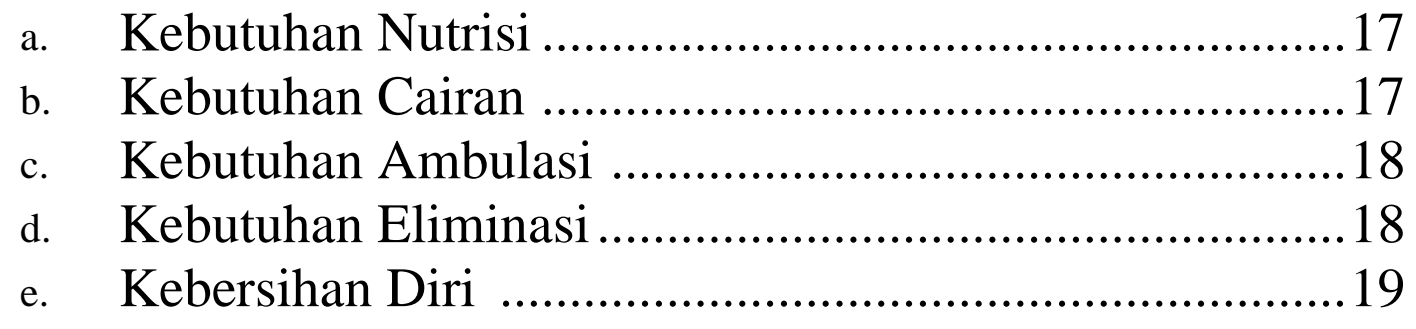


f. Kebutuhan Istirahat dan Tidur ....................................21

g. Kebutuhan Seksual .....................................................21

h. Kebutuhan Perawatan Payudara ..................................22

i. Latihan Senam Nifas ..................................................23

j. Rencana KB...........................................................24

BAB V KOMPLIKASI DAN PENYAKIT DALAM MASA NIFAS
a. Infeksi Nifas .25
b. Infeksi Saluran Kemih ................................................25

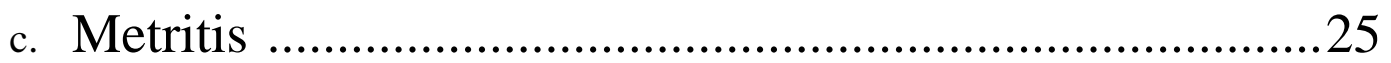

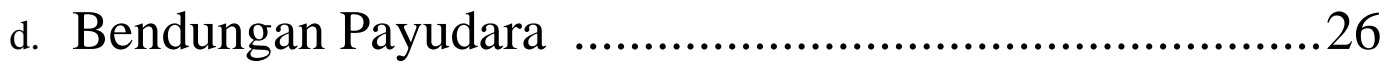
e. Infeksi Payudara ......................................................26
f. Abses Payudara ......................................................26
g. Abses Pelvis .............................................................26

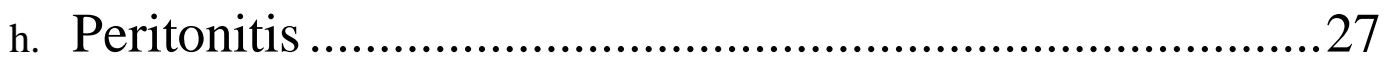
i. Infeksi Luka Perineum dan Luka Abdominal .................27
j. Perdarahan Pervagina...................................................27

\section{BAB VI TEORI MANAJEMEN KEBIDANAN}

a. Pengertian ....................................................................... 31

1. Tahap Pengumpulan Data Dasar ................................... 32

2. Interprestasi Data Dasar ..............................................33

3. Identifikasi Diagnosis/Masalah Potensial dan Antisipasi Penanganannya (Langkah III).....................34

4. Menetapkan Perlunya Konsultasi dan Kolaborasi Segera dengan Tenaga Kesehatan Lain (Langkah IV) ....35

5. Menyusun Rencana Asuhan Menyeluruh(Langkah

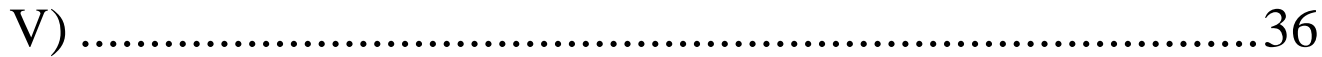

6. Pelaksanaan Langsung Asuhan dengan Efesien dan Aman(Langkah VI) ......................................................36

7. Evaluasi(Langkah VII) ..............................................36

8. Manajemen kebidanan dengan metode SOAP .................37

9. Teori Hukum Kewenangan Bidan .................................. 38 
BAB VII CONTOH SOAL ..............................................41 KUNCI JAWABA .............................................................45

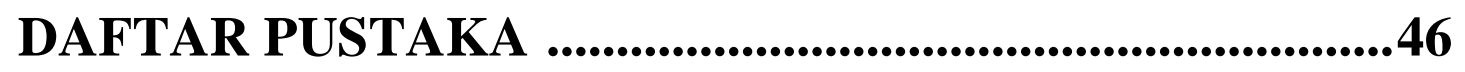




\section{BAB I \\ KONSEP DASAR MASA NIFAS}

\section{Pengertian}

Masa nifas atau masa puerperium adalah masa setelah persalinan selesai sampai 6 minggu atau 42 hari. Selama masa nifas, organ reproduksi secara perlahan akan mengalami perubahan seperti keadaan sebelum hamil. Perubahan organ reproduksi ini disebut involus (Maritalia, 2012).

\section{Tahapan Masa Nifas}

Menurut Maritalia (2012) masa nifas dibagi menjadi 3 tahap, yaitu:

a. Puerperium dini

Puerperium dini merupakan masa pemulihan awal dimana ibu diperbolehkan untuk berdiri dan berjalan-jalan. Ibu yang melahirkan per vagina tanpa komplikasi dalam 6 jam pertama setelah kala IV dianjurkan untuk mobilisasi segera.

b. Puerperium intermedial

Suatu masa pemulihan dimana organ-organ reproduksi secara berangsur-angsur akan kembali ke keadaan sebelum hamil. Masa ini berlangsung selama kurang lebih enam minggu atau 42 hari. 
c. Remote puerperium

Waktu yang diperlukan untuk pulih dan sehat kembali dalam keadaan sempurna terutama bila ibu selama hamil atau waktu persalinan mengalami komplikasi. Rentang waktu remote puerperium berbeda untuk setiap ibu, tergantung dari berat ringannya komplikasi yang dialami selama hamil atau persalinan. 


\section{BAB II \\ PERUBAHAN FISIOLOGIS MASA NIFAS}

Ibu dalam masa nifas mengalami perubahan fisiologis. Setelah keluarnya plasenta, kadar sirkulasi hormon HCG (human chorionic gonadotropin), human plasental lactogen, estrogen dan progesteron menurun. Human plasental lactogen akan menghilang dari peredaran darah ibu dalam 2 hari dan HCG dalam 2 mingu setelah melahirkan. Kadar estrogen dan progesteron hampir sama dengan kadar yang ditemukan pada fase follikuler dari siklus menstruasi berturut-turut sekitar 3 dan 7 hari. Penarikan polipeptida dan hormon steroid ini mengubah fungsi seluruh sistem sehingga efek kehamilan berbalik dan wanita dianggap sedang tidak hamil (Walyani, 2017)

Perubahan- perubahan fisiologis yang terjadi pada ibu masa nifasmenurut Maritalia (2012) dan Walyani (2017) yaitu:

\section{a. Uterus}

Uterus merupakan organ reproduksi interna yang berongga dan berotot, berbentuk seperti buah alpukat yang sedikit gepeng dan berukuran sebesar telur ayam. Panjang uterus sekitar 7-8 $\mathrm{cm}$, lebar sekitar 5-5,5 cm dan tebal sekitar 2, $5 \mathrm{~cm}$. Letak uterus secara fisiologis adalah anteversiofleksio. Uterus terbagi dari 3 bagian yaitufundus uteri, korpus uteri, dan serviks uteri.

Menurut Walyani (2017) uterus berangsur- angsur menjadi kecil (involusi) sehingga akhirnya kembali seperti sebelum hamil:

1. Bayi lahir fundus uteri setinggi pusat dengan berat uterus 1000 gr.

2. Akhir kala III persalinan tinggi fundus uteri teraba 2 jari bawah pusat dengan berat uterus $750 \mathrm{gr}$.

3. Satu minggu postpartum tinggi fundus uteri teraba pertengahan pusat dengan simpisis, berat uterus $500 \mathrm{gr}$. 
4. Dua minggu postpartum tinggi fundus uteri tidak teraba diatas simpisis dengan berat uterus 350 gr.

5. Enam minggu postpartum fundus uteri bertambah kecil denganberat uterus $50 \mathrm{gr}$.

Pemeriksaan uterus meliputi mencatat lokasi, ukuran dan konsistensi antara lain:

1) Penentuan lokasi uterus

Dilakukan dengan mencatat apakah fundus berada diatas atau dibawah umbilikus dan apakah fundus berada digaris tengah abdomen/ bergeser ke salah satu sisi.

2) Penentuan ukuran uterus

Dilakukan melalui palpasi dan mengukur TFU pada puncak fundus dengan jumlah lebar jari dari umbilikus atas atau bawah.

3) Penentuan konsistensi uterus

Ada 2 ciri konsistensi uterus yaitu uterus kerasa terabasekeras batu dan uterus lunak.

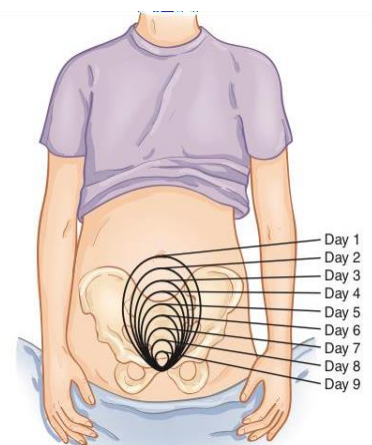

Gambar 1. I 1ngg1 rundus Uteri

b. Serviks

Serviks merupakan bagian dasar dari uterus yang bentuknya menyempit sehingga disebut juga sebagai leher rahim. Serviks menghubungkan uterus dengan saluran vagina dan 
sebagai jalan keluarnya janin dan uterus menuju saluran vagina pada saat persalinan. Segera setelah persalinan, bentuk serviks akan menganga seperti corong. Hal ini disebabkan oleh korpus uteri yang berkontraksi sedangkan serviks tidak berkontraksi. Warna serviks berubah menjadi merah kehitaman karena mengandung banyak pembuluh darah dengan konsistensi lunak.

Segera setelah janin dilahirkan, serviks masih dapat dilewati oleh tangan pemeriksa. Setelah 2 jam persalinan serviks hanya dapat dilewati oleh 2-3 jari dan setelah 1 minggu persalinan hanya dapat dilewati oleh 1 jari, setelah 6 minggu persalinan serviks menutup.

c. Vagina

Vagina merupakan saluran yang menghubungkan rongga uterus dengan tubuh bagian luar. Dinding depan dan belakang vagina berdekatan satu sama lain dengan ukuran panjang $\pm 6,5$ $\mathrm{cm}$ dan $\pm 9 \mathrm{~cm}$.

Selama proses persalinan vagina mengalami penekanan serta pereganganan yang sangat besar, terutama pada saat melahirkan bayi. Beberapa hari pertama sesudah proses tersebut, vagina tetap berada dalam keadaan kendur. Setelah 3 minggu vagina kembali kepada keadaan tidak hamil dan rugae dalam vagina secara berangsur- angsurakan muncul kembali.

Sesuai dengan fungsinya sebagai bagian lunak dan jalan lahir dan merupakan saluran yang menghubungkan cavum uteri dengan tubuh bagian luar, vagina juga berfungsi sebagai saluran tempat dikeluarkannya sekret yang berasal dari cavum uteri selama masa nifas yang disebut lochea.

Karakteristik lochea dalam masa nifas adalah sebagai berikut:

\section{Lochea rubral kruenta}


Timbul pada hari 1- 2 postpartum, terdiri dari darah segar barcampur sisa- sisa selaput ketuban, sel- sel desidua, sisa- sisa verniks kaseosa, lanugo dan mekoneum.

2. Lochea sanguinolenta

Timbul pada hari ke 3 sampai dengan hari ke 7 postpartum, karakteristik lochea sanguinolenta berupa darah bercampur lendir.

3. Lochea serosa

Merupakan cairan berwarna agak kuning, timbul setelah 1 minggu postpartum.

\section{Lochea alba}

Timbul setelah 2 minggu postpartum dan hanya merupakancairan putih (Walyani, 2017)

Normalnya lochea agak berbau amis, kecuali bila terjadi infeksi pada jalan lahir, baunya akan berubah menjadi berbau busuk.

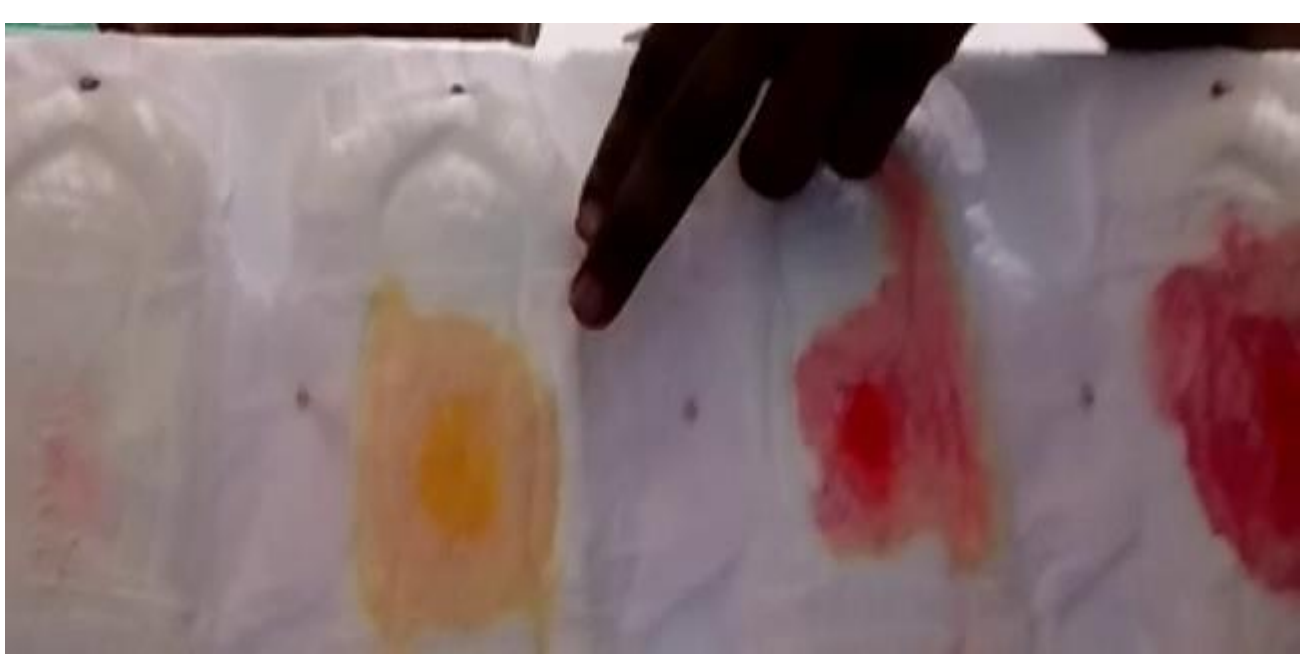

Gambar 2. Warna Lochea 
d. Vulva

Sama halnya dengan vagina, vulva juga mengalami penekanan serta peregangan yang sangat besar selama proses melahirkan bayi. Beberapa hari pertama sesudah proses melahirkan vulva tetap berada dalam keadaan kendur. Setelah 3 minggu vulva akan kembali kepadakeadaan tidak hamil dan labia menjadi lebih menonjol.

e. Payudara (mamae)

Setelah pelahiran plasenta, konsentrasi estrogen dan progesteron menurun, prolactin dilepaskan dan sintesis ASI dimulai. Suplai darah ke payudara meningkat dan menyebabkan pembengkakan vascular sementara. Air susu sata diproduksi disimpan di alveoli dan harus dikeluarkan dengan efektif dengan cara dihisap oleh bayi untuk pengadaan dan keberlangsungan laktasi.

ASI yang akan pertama muncul pada awal nifas ASI adalah ASI yang berwarna kekuningan yang biasa dikenal dengan sebutan kolostrum. Kolostrum telah terbentuk didalam tubuh ibu pada usia kehamilan \pm 12 minggu.

Perubahan payudara dapat meliputi:

1. Penurunan kadar progesteron secara tepat dengan peningkatanhormon prolactin setelah persalinan.

2. Kolostrum sudah ada saat persalinan produksi ASI terjadi pada harike 2 atau hari ke 3 setelah persalinan

3. Payudara menjadi besar dan keras sebagai tanda mulainya proseslaktasi (Walyani, 2017)

f. Tanda- tanda vital

Perubahan tanda- tanda vital menurut Maritalia (2012) dan Walyani (2017) antara lain: 
1. Suhu tubuh

Setelah proses persalinan suhu tubuh dapat meningkat $0,5^{\circ}$ celcius dari keadaan normal namun tidak lebih dari $38^{\circ}$ celcius. Setelah 12 jam persalinan suhu tubuh akan kembali seperti keadaansemula.

2. Nadi

Setelah proses persalinan selesai frekuensi denyut nadi dapat sedikit lebih lambat. Pada masa nifas biasanya denyut nadi akan kembali normal.

3. Tekanan darah

Setelah partus, tekanan darah dapat sedikit lebih rendah dibandingkan pada saat hamil karena terjadinya perdarahan pada proses persalinan.

4. Pernafasan

Pada saat partus frekuensi pernapasan akan meningkat karena kebutuhan oksigen yang tinggi untuk tenaga ibu meneran/ mengejan dan memepertahankan agar persediaan oksigen ke janin tetap terpenuhi. Setelah partus frekuensi pernafasan akan kembali normal.

g. Sistem peredaran darah (Kardiovaskuler)

Denyut jantung, volume dan curah jantung meningkat segera setelah melahirkan karena terhentinya aliran darah ke plasenta yang mengakibatkan beban jantung meningkat yang dapat diatasi dengan haemokonsentrasi sampai volume darah kembali normal, danpembulu darah kembali ke ukuran semula.

h. Sistem pencernaan

Pada ibu yang melahirkan dengan cara operasi (section 
caesarea) biasanya membutuhkan waktu sekitar 1- 3 hari agar fungsi saluran cerna dan nafsu makan dapat kembali normal. Ibu yang melahirkan secara spontan biasanya lebih cepat lapar karena telah mengeluarkan energi yang begitu banyak pada saat proses melahirkan.

Buang air besar biasanya mengalami perubahan pada 1- 3 hari postpartum, hal ini disebabkan terjadinya penurunan tonus otot selama proses persalinan. Selain itu, enema sebelum melahirkan, kurang asupan nutrisi dan dehidrasi serta dugaan ibu terhadap timbulnya rasa nyeri disekitar anus/ perineum setiap kali akan b.a.b juga mempengaruhi defekasi secara spontan. Faktorfaktor tersebut sering menyebabkan timbulnya konstipasi pada ibu nifas dalam minggu pertama. Kebiasaan defekasi yang teratur perlu dilatih kembali setelah tonus otot kembali normal.

i. Sistem perkemihan

Buang air kecil sering sulit selama 24 jam pertama. Kemungkinan terdapat spasine sfingter dan edema leher bulibuli sesudah bagian ini mengalami kompresi antara kepala janin dan tulang pubis selama persalinan. Urine dalam jumlah yang besar akan dihasilkan dalam waktu 12- 36 jam sesudah melahirkan. Setelah plasenta dilahirkan, kadar hormon estrogen yang bersifat menahan air akan mengalami penurunan yang mencolok. Keadaan ini menyebabkan diuresis. Uterus yang berdilatasi akan kembali normal dalam tempo 6 minggu.

j. Sistem integumen

Perubahan kulit selama kehamilan berupa hiperpigmentasi pada wajah, leher, mamae, dinding perut dan beberapa lipatan sendri karena pengaruh hormon akan menghilang selama masa nifas. 
k. Sistem musculoskeletal

Ambulasi pada umumnya dimulai 4- 8 jam postpartum. Ambulasi dini sangat membantu untuk mencegah komplikasi dan mempercepat proses involusi. 


\section{BAB III PERUBAHAN PSIKOLOGIS MASA NIFAS}

Adanya perasaan kehilangan sesuatu secara fisik sesudah melahirkan akan menjurus pada suatu reaksi perasaan sedih. Kemurungan dan kesedihan dapat semakin bertambah oleh karena ketidaknyamanan secara fisik, rasa letih setelah proses persalinan, stress, kecemasan, adanya ketegangan dalam keluarga, kurang istirahat karena harus melayani keluarga dan tamu yang berkunjung untuk melihat bayi atau sikap petugas yang tidak ramah (Maritalia, 2012).

Minggu- minggu pertama masa nifas merupakan masa rentan bagi seorang ibu. Pada saat yang sama, ibu baru (primipara) mungkin frustasi karena merasa tidak kompeten dalam merawat bayi dan tidak mampu mengontrol situasi. Semua wanita akan mengalami perubahan ini, namun penanganan atau mekanisme koping yang dilakukan dari setiap wanita untuk mengatasinya pasti akan berbeda. Hal ini dipengaruhi oleh pola asuh dalam keluarga dimana wanita tersebut dibesarkan, lingkungan, adat istiadat setempat, suku, bangsa, pendidikan serta pengalaman yang didapat (Maritalia, 2012).

Perubahan psikologis yang terjadi pada ibu masa nifas menurut Maritalia (2012) yaitu:

a. Adaptasi psikologis ibu dalam masa nifas

Pada primipara, menjadi orang tua merupakan pengalaman tersendiri dan dapat menimbulkan stress apabila tidak ditangani dengan segera. Perubahan peran dari wanita biasa menjadi seorang ibu memerlukan adaptasi sehingga ibu dapat melakukan perannya dengan baik. Perubahan hormonal yang sangat cepat setelah proses melahirkan juga ikut mempengaruhi keadaan emosi dan proses adaptasi ibu pada masa nifas. Fase- fase yang akan dialami oleh ibu pada masa nifas menurut Dewi (2012) antara lain adalah sebagai berikut: 


\section{Fase taking in}

Fase taking in merupakan fase ketergantungan yang berlangsung dari hari pertama sampai hari kedua setelah melahirkan. Ibu terfokus pada dirinya sendiri sehingga cenderung pasif terhadap lingkungannya. Ketidaknyamanan yang dialami ibu lebih disebabkan karena proses persalinan yang baru saja dilaluinya. Rasa mules, nyeri pada jalan lahir, kurang tidur atau kelelahan, merupakan hal yang sering dikeluhkan ibu. Pada fase ini, kebutuhan istirahat, asupan nutrisi dan komunikasi yang baik harus dapat terpenuhi.

Bila kebutuhan tersebut tidak terpenuhi, ibu dapat mengalami gangguan psikologis berupa kekecewaan pada bayinya, ketidaknyamanan sebagai akibat perubahan fisik yang dialami, rasa bersalah karena belum bisa menyusui bayinya dan kritikan suami atau keluarga tentang perawatan bayinya.

\section{Fase taking hold}

Fase taking hold merupakan fase yang berlangsung antara 3- 10 hari setelah melahirkan. Ibu merasa khawatir akan ketidakmampuan dan rasa tanggung jawab dalam perawatan bayinya. Perasaan ibu lebih sensitif sehingga mudah tersinggung. Hal yang perlu diperhatikan adalah komunikasi yang baik, dukungan dan pemberian penyuluhan atau pendidikan kesehatan tentang perawatan diri dan bayinya.

\section{Fase letting go}

Fase ini merupakan fase menerima tanggung jawab peran barunya sebagai seorang ibu. Fase ini berlangsung selama 10 hari setelah melahirkan. Ibu sudah mulai dapat menyesuaikan diri dengan ketergantungan bayinya dan siap menjadi pelindung bagi bayinya. Perawatan ibu terhadap 
diri dan bayinya semakin meningkat.

Rasa percaya diri ibu akan peran barunya mulai tumbuh, lebih mandiri dalam memenuhi kebutuhan dirinya dan bayinya. Dukungan suami dan keluarga dapat membantu ibu untuk lebih meningkatkan rasa percaya diri dalam merawat bayinya. Kebutuhan akan istirahat dan nutrisi yang cukup masih sangat diperlukan ibu untuk menjaga kondisi fisiknya.

\section{b. Postpartum blues (Baby blues)}

Postpartum blues merupakan perasaan sedih yang dialami oleh seorang ibu berkaitan dengan bayinya. Biasanya muncul sekitar 2 hari sampai 2 minggu sejak kelahiran bayi. Keadaan ini disebabkan oleh perubahan perasaan yang dialami ibu saat hamil sehingga sulit menerima kehadiran bayinya.

Ibu yang mengalami baby blues akan mengalami perubahan perasaan, menangis, cemas, kesepian khawatir, yang berlebihan mengenai sang bayi, penurunan gairah sex, dan kurang percaya diri terhadap kemampuan menjadi seorang ibu. Jika hal ini terjadi, ibu disarankan untuk melakukan hal- hal berikut ini:

1. Minta suami atau keluarga membantu dalam merawat bayi atau melakukan tugas- tugas rumah tangga sehingga ibu bisa cukup istirahat untuk menghilangkan kelelahan.

2. Komunikasikan dengan suami atau keluarga mengenai apa yang sedang ibu rasakan, mintalah dukungan dan pertolongannya

3. Buang rasa cemas dan kekhawatiran yang berlebihan akan kemampuan merawat bayi

4. Carilah hiburan dan luangkan waktu untuk istirahat dan menyenangkan diri sendiri, misalnya dengan cara menonton, 
membaca, atau mendengar musik (Maritalia, 2012).

\section{c. Depresi postpartum}

Seorang ibu primipara lebih beresiko mengalami kesedihan atau kemurungan postpartum karena ia belum mempunya pengalaman dalam merawat dan menyusui bayinya. Kesedihan atau kemurungan yang terjadi pada awal masa nifas merupakan hal yang umum dan akan hilang sendiri dalam dua minggu sesudah melahirkan setelah ibumelewati proses adaptasi.

Ada kalanya ibu merasakan kesedihan karena kebebasan, otonomi, interaksi sosial, kemandiriannya berkurang setelah mempunyai bayi. Hal ini akan mengakibatkan depresi pascapersalinan (depresi postpartum). Ibu yang mengalami depresi postpartum akan menunjukkan tanda- tanda berikut: sulit tidur, tidak ada nafsu makan, perasaan tidak berdaya atau kehilangan kontrol, terlalu cemas atau tidak perhatian sama sekali pada bayi, tidak menyukai atau takut menyentuh bayi, pikiran yang menakutkan mengenai bayi, sedikit atau tidak ada perhatian terhadap penampilan bayi, sedikit atau tidak ada perhatian terhadap penampilan diri, gejala fisik seperti sulit bernafas atau perasan berdebar- debar. Jika ibu mengalami sebagian dari tanda- tanda seperti yang diatas sebaiknya segera lakukan konseling pada ibu dan keluarga.

d. Respon antara ibu dan bayi setelah persalinan

Respon antara ibu dan bayi setelah persalinan menurut Maritalia (2012) antara lain:

\section{Touch (Sentuhan)}

Sentuhan yang dilakukan ibu pada bayinya seperti membelai- belai kepala bayi dengan lembut, mencium bayi, menyentuh wajah dan ektremitas, memeluk dan 
menggendong bayi, dapat membuat bayi merasa aman dan nyaman. Biasanya bayi akan memeberikan respon terhadap sentuhan ibu dengan cara menggenggam jari ibu atau memegang seuntai rambut ibu. Gerakan lembut ibu ketika menyentuh bayinya akan menenangkanbayi.

\section{Eye to eye contact (Kontak mata)}

Kontak mata mempunya efek yang erat terhadap perkembangan dimulainya hubungan dan rasa percaya sebagai faktor yang penting sebagai hubungan antar manusia pada umumnya. Bayi baru lahir dapat memusatkan perhatian pada suatu obyek, satu jam setelah kelahiran pada jarak sekitar 20- $25 \mathrm{~cm}$, dan dapat memusatkan pandangan sebaik orang dewasa pada usia sekita 4 bulan. Kontak mata antara ibu dan bayinya harus dilakukan sesegera mungkin setelah bayi lahir.

3. Odor (Bau badan)

Pada akhir minggu pertama kehidupannya seorang bayi dapat mengenali ibunya dari bau badan dan air susu ibunya. Indra penciuman bayi akan terus terasah jika seorang ibu dapat terus memberikan ASI pada bayinya.

4. Body warm (Kehangatan tubuh)

Bayi baru lahir sangat mudah mengalami hypothermi karena tidak ada lagi air ketuban yang melindungi dari perubahan suhu yang terjadi secara ekstrim di luar uterus. Jika tidak ada komplikasi yang serius pada ibu dan bayi selama persalinan, bayi dapat diletakkan di atas perut ibu segera setelah dilakukan pemotongan tali pusat.

\section{Voice (Suara)}

Sejak dilahirkan, bayi dapat mendengar suara- suara 
dan membedakan nada, meskipun suara- suara terhalang selama beberapa hari oleh cairan amnion dari rahim yang melekat pada telinga.

6. Entrainment (Gaya Bahasa)

Bayi baru lahir mulai membedakan dan menemukan perubahan struktur bicara dan bahasa dari orang- orang yang berada disekitarnya. Perubahan nada suara ibu ketika berkomunikasi dengan bayinya seperti bercerita, mengajak bercanda atau sering memarahi bayi, secara perlahan mulai dapatdipahami dan dipelajari bayi.

7. Biorhythmic (Irama kehidupan)

Selama lebih kurang 40 minggu di dalam rahim, janin terbiasa mendengar suara detak jantung ibu. Dari suara detak jantung tersebut, janin mencoba mengenali biorhythmic ibunya dan menyesuaikan dengan irama dirinya sendiri. Setelah lahir, suara detak jantung ibu masih akan berpengaruh terhadap bayi. 


\section{BAB IV}

\section{KEBUTUHAN DASAR IBU MASA NIFAS}

Kebutuhan dasar pada ibu masa nifas menurut Maritalia (2012) dan Walyani (2017) yaitu:

a. Kebutuhan nutrisi

Ibu nifas harus mengkonsumsi makanan yang mengandung zat- zat yang berguna bagi tubuh ibu pasca melahirkan dan untuk persiapan prosuksi ASI, terpenuhi kebutuhan karbohidrat, protein, zat besi, vitamin dan minelar untuk mengatasi anemia, cairan dan serat untuk memperlancar ekskresi. Ibu nifas harus mengkonsumsi makanan yang mengandung zat- zat yang berguna bagi tubuh ibu pasca melahirkan dan untuk persiapan prosuksi ASI, terpenuhi kebutuhan karbohidrat, protein, zat besi, vitamin dan minelar untuk mengatasi anemia, cairan dan serat untuk memperlancar ekskresi.

Kebutuhan kalori wanita dewasa yang sehat dengan berat badan $47 \mathrm{~kg}$ diperkirakan sekitar 2200 kalori/ hari. Ibu yang berada dalam masa nifas dan menyusui membutuhkan kalori yang sama dengan wanita dewasa, ditambah 700 kalori pada 6 bulan pertama untuk membeikan ASI eksklusif dan 500 kalori pada bulan ke tujuh dan selanjutnya.

b. Kebutuhan cairan

Fungsi cairan sebagai pelarut zat gizi dalam proses metabolisme tubuh. Minumlah cairan cukup untuk membuat tubuh ibu tidak dehidrasi. Ibu dianjurkan untuk minum setiap kali menyusui dan menjaga kebutuhan hidrasi sedikitnya 3 liter setiap hari. Asupan tablet tambah darah dan zat besi diberikan selama 40 hari postpartum. Minum kapsul Vit A (200.000 unit). 
c. Kebutuhan ambulasi

Aktivitas dapat dilakukan secara bertahap, memberikan jarak antara aktivitas dan istirahat. Dalam 2 jam setelah bersalin ibu harus sudah melakukan mobilisasi. Dilakukan secara perlahan- lahan dan bertahap. Dapat dilakukan dengan miring kanan atau kiri terlebih dahulu dan berangsur- angsur untuk berdiri dan jalan.

Mobilisasi dini bermanfaat untuk:

1. Melancarkan pengeluaran lokia, mengurangi infeksi puerperium.

2. Ibu merasa lebih sehat dan kuat.

3. Mempercepat involusi alat kandungan.

4. Fungsi usus, sirkulasi, paru- paru dan perkemihan lebih baik.

5. Meningkatkan kelancaran peredaran darah, sehingga mempercepatfungsi ASI dan pengeluaran sisa metabolisme.

6. Memungkinkan untuk mengajarkan perawatan bayi pada ibu.

7. Mencegah trombosis pada pembuluh tungkai (Walyani, 2017).

d. Kebutuhan eliminasi

Pada kala IV persalinan pemantauan urin dilakukan selama 2 jam, setiap 15 menit sekali pada 1 jam pertama dan 30 menit sekali pada jam berikutnya. Pemantauan urin dilakukan untuk memastikan kandung kemih tetap kosong sehingga uterus dapat berkontraksi dengan baik. Dengan adanya kontraksi uterus yang adekuat diharapkan perdarahan postpartum dapat dihindari.

Memasuki masa nifas, ibu diharapkan untuk berkemih dalam 6- 8 jam pertama. Pengeluaran urin masih tetap dipantau dan diharapkan setiap kali berkemih urin yang keluar minimal sekitar $150 \mathrm{ml}$. Ibu nifas yang mengalami kesulitan dalam berkemih 
kemungkinan disebabkan oleh menurunnya tonus otot kandung kemih, adanya edema akibat trauma persalinan dan rasa takut timbulnya rasa nyeri setiap kali berkemih.

Kebutuhan untuk defekasi biasanya timbul pada hari pertama sampai hari ke tiga postpartum. Kebutuhan ini dapat terpenuhi bila ibu mengkonsumsi makanan yang mengandung tinggi serat, cukup cairan dan melakukan mobilisasi dengan baik dan benar. Bila lebih dari waktu tersebut ibu belum mengalami defekasi mungkin perludiberikan obat pencahar.

e. Kebersihan diri

Pada masa nifas yang berlangsung selama lebih kurang 40 hari, kebersihan vagina perlu mendapat perhatian lebih. Vagina merupakan bagian dari jalan lahir yang dilewati janin pada saat proses persalinan. Kebersihan vagina yang tidak terjaga dengan baik pada masa nifas dapat menyebabkan timbulnya infeksi pada vagina itu sendiri yang dapat meluas sampai ke rahim.

Alasan perlunya meningkatkan kebersihan vagina pada masa nifas adalah:

1. Adanya darah dan cairan yang keluar dari vagina selama masa nifasyang disebut lochea.

2. Secara anatomis, letak vagina berdekatan dengan saluran buang airkecil (meatus eksternus uretrae) dan buang air besar (anus) yang setiap hari kita lakukan. Kedua saluran tersebut merupakan saluran pembuangan (muara eksreta) dan banyak mengandung mikroorganisme pathogen.

3. Adanya luka/ trauma di daerah perineum yang terjadi akibat prosespersalinan dan bila terkena kotoran dapat terinfeksi.

4. Vagina merupakan organ terbuka yang mudah dimasuki mikroorganisme yang dapat menjalar ke rahim (Maritalia, 2012). Untuk menjaga kebersihan vagina pada masa nifas dapat dilakukan dengan cara: 
1) Setiap selesai b.a.k atau b.a.b siramlah mulut vagina dengan air bersih. Basuh dari arah depan ke belakang hingga tidak ada sisa- sisa kotoran yang menempel disekitar vagina baik itu urin maupun feses yang mengandung mikroorganisme dan bisa menimbulkan infeksi pada luka jahitan

2) Bila keadaan vagina terlalu kotor, cucilah dengan sabun atau cairan antiseptic yang berfungsi untuk menghilangkan mikroorganisme yang terlanjur berkembangbiak di darah tersebut

3) Bila keadaan luka perineum terlalu luas atau ibu dilakukan episitomi, upaya untuk menjaga kebersihan vagina dapat dilakukan dengan cara duduk berendam dalam cairan antiseptic selama 10 menit setelah b.a.k atau b.a.b

4) Mengganti pembalut setiap selesai membersihkan vagina agar mikroorganisme yang ada pada pembalut tersebut tidak ikut terbawa ke vagina yang baru dibersihkan

5) Keringkan vagina dengan tisu atau handuk lembut setiap kali selesai membasuh agar tetap kering dan kemudian kenakan pembalut yang baru. Pembalut harus diganti setiap selesai b.a.k atau b.a.b atau minimal 3 jam sekali atau bila ibu sudah merasa tidak nyaman

6) Bila ibu membutuhkan salep antibiotic, dapat dioleskan sebelum pembalut yang baru (Maritalia, 2012).

Dibawah ini yang merupakan tanda- tanda infeksi yang bisa dialami ibu pada masa nifas apabila tidak melakukan perawatan vagina dengan baik:

1) Suhu tubuh pada aksila melebihi $37,5^{\circ} \mathrm{C}$.

2) Ibu menggigil, pusing, dan mual.

3) Keputihan yang berbau. 
4) Keluar cairan seperti nanah dari vagina yang disertai bau dan rasanyeri.

5) Terasa nyeri di perut.

6) Terjadinya perdarah pervagina yang lebih banyak dari biasanya(Maritalia, 2012)

f. Kebutuhan istirahat dan tidur

Ibu nifas memerlukan istirahat yang cukup, istirahat tidur yang dibutuhkan ibu nifas sekitar 8 jam pada malam hari dan 1 jam pada siang hari. Pada tiga hari pertama dapat merupakan hari yang sulit bagi ibu akibat menumpuknya kelelahan karena proses persalinan dan nyeri yang timbul pada luka perineum. Secara teoritis, pola tidur akan kembali mendekati normal dalam 2 sampai 3 minggu setelah persalinan.

Pada ibu nifas, kurang istirahat akan mengakibatkan:

1. Berkurangnya produksi ASI.

2. Memperlambat proses involusi uterus dan meningkatkan perdarahan.

3. Menyebabkan depresi dan ketidakmampuan untuk merawat bayidan dirinya sendiri (Maritalia, 2012).

g. Kebutuhan seksual

Ibu yang baru melahirkan boleh melakukan hubungan seksual kembali setelah 6 minggu persalinan. Batasan waktu 6 minggu didasarkan atas pemikiran pada masa itu semua luka akibat persalinan, termasuk luka episiotomi dan luka bekas section caesarea (SC) biasanya telah sembuh dengan baik. Bila suatu persalinan dipastikan tidak ada luka atau laserasi/ robek pada jaringan, hubungan seks bahkan telah boleh dilakukan 3- 4 minggu setelah proses melahirkan. Meskipun hubungan telah dilakaukan setelah minggu ke- 6 adakalanya ibu- ibu tertentu 
mengeluh hubungan masih terasa sakitatau nyeri meskipun telah beberapa bulan proses persalinan. Gangguan seperti ini disebut dispareunia atau rasa nyeri waktu senggama. Ada beberapa kemungkinan yang dapat menyebabkan dispareunia:

1. Setelah melahirkan ibu- ibu sering mengkonsumsi jamujamu tertentu. Jamu- jamu ini mungkin mengandung zat- zat yang memiliki sifat astringents yang berakibat menghambat produksi cairan pelumas pada vagina saat seorang wanita terangsang seksual.

2. Jaringan baru yang terbentuk karena proses penyembuhan lukaguntingan jalan lahir masih sensitif.

3. Faktor psikologis yaitu kecemasan yang berlebihan (Maritalia, 2012).

h. Kebutuhan perawatan payudara

Menurut Walyani (2017) kebutuhan perawatan payudara padaibu masa nifas antara lain:

1. Sebaiknya perawatan mamae telah dimulai sejak wanita hamil supaya puting lemas, tidak keras dan kering sebagai persiapan untuk menyusui bayinya.

2. Bila bayi meninggal, laktasi harus dihentikan dengan cara: pembalutan mamae sampai tertekan, pemberian obat estrogen untuk supresi LH seperti tablet Lynoral dan Pardolel.

3. Ibu menyusi harus menjaga payudaranya untuk tetap bersih dan kering.

4. Menggunakan bra yang menyongkong payudara.

5. Apabila puting susu lecet oleskan kolostrum atau ASI yang keluar pada sekitar putting susu setiap kali selesai menyusui, kemudian apabila lecetnya sangat berat dapat diistirahatkan selama 24 jam. Asi dikeluarkan dan diminumkan 
menggunakan sendok. Selain itu, untuk menghilangkan rasa nyeri dapat minum paracetamol 1 tabletsetiap 4- 6 jam.

i. Latihan senam nifas

Pada masa nifas yang berlangsung selama lebih kurang 6 minggu, ibu membutuhkan latihan- latihan tertentu yang dapat mempercepat proses involusi. Salah satu latihan yang dianjurkan padamasa ini adalah senam nifas. Senam nifas adalah senam yang dilakukan oleh ibu setelah persalinan, setelah keadaan ibu normal.

Senam nifas sebaiknya dilakukan dalam 24 jam setelah persalinan, secara teratur setiap hari. Luka yang timbul akibat proses persalinan karena 6 jam setelah persalinan normal dan 8 jam setelah persalinan Caesar, ibu sudah dianjurkan untuk mobilisasi dini. Tujuan utama mobilisasi dini adalah agar peredaran darah ibu dapat berjalan dengan baik sehingga ibu dapat melakukan senam nifas.

Bentuk latihan senam nifas antara ibu yang melahirkan secara normal dengan ibu yang melahirkan Caesar tentu akan berbeda. Pada ibu yang mengalami persalinan Caesar, beberapa jam setelah keluar dari kamar operasi, pernafasan lah yang dilatih guna mempercepat penyembuhan luka operasi, sementara latihan untuk mengencangkan otot perut dan melancarkan sirkulasi darah di tungkai baru dilakukan 2- 3 hari setelah ibu dapat bangun dari tempat tidur. Sedangkan pada persalinan normal, bila keadaan ibu cukup baik, semua gerakan senam bisa dilakukan.

Manfaat senam nifas menurut Maritalia (2012) antara lain:

1. Memperbaiki sirkulasi darah sehingga mencegah terjadinya pembekuan (trombosis) pada pembuluh darah terutama pembuluh tungkai.

2. Memperbaiki sikap tubuh selama kehamilan dan persalinan denganmemulihkan dan menguatkan otot- otot punggung.

3. Memperbaiki tonus otot pelvis. 
4. Memperbaiki regangan otot tungkai bawah.

5. Memperbaikiregangan otot abdomen setelah hamil dan melahirkan.

6. Meningkatkan kesadaran untuk melakukan relaksasi ototototdasar panggul.

7. Mempercepat terjadinya proses involusi organ- organ reproduksi.

Tidak semua ibu setelah persalinan dapat melakukan senam nifas. Untuk ibu- ibu yang mengalami komplikasi selama persalinan tidak dibolehkan melakukan senam nifas. Demikian juga untuk penderita kelainan seperti jantung, ginjal atau diabetes.

j. Rencana KB

Rencana KB setelah ibu melahirkan sangatlah penting, dikarenakan secara tidak langsung KB dapat membantu ibu untuk dapat merawat anaknya dengan baik serta mengistirahatkan alat kandungnya. 


\section{BAB V}

\section{KOMPLIKASI DAN PENYAKIT DALAM MASA NIFAS}

Komplikasi dan penyakit yang terjadi pada ibu masa nifas menurut Walyani (2017) yaitu:

a. Infeksi nifas

Infeksi nifas adalah keadaan yang mencakup semua peradangan alat- alat genetelia dalam masa nifas. Masuknya kuman- kuman dapat terjadi dalam kehamilan, waktu persalinan, dan nifas. Demam nifas adalah demam dalam masa nifas oleh sebab apa pun. Morbiditas puerpuralis adalah kenaikan suhu badan sampai $38^{\circ} \mathrm{C}$ atau lebih selama 2 hari dari dalam 10 hari postpartum. Kecuali pada hari pertama. Suhu diukur 4 kali secara oral.

b. Infeksi saluran kemih

Pada masa nifas dini, sensitivitas kandung kemih terhadap tegangan air kemih di dalam vesika sering menurun akibat trauma persalinan atau analgesia epidural atau spinal. Sensasi peregangan kandung kemih juga mungkin berkurang akibat rasa tidak nyaman yang ditimbulkan oleh episiotomi yang lebar, laserasi periuretra, atau hematoma dinding vagina. Setelah melahirkan, terutama saat infus oksitosis dihentikan, terjadi diuresis yang disertai peningkatan produksi urin dan distensi kandung kemih. Over distensi yang disertai katerisasi untuk mengeluarkan air kemih sering menyebabkan infeksisaluran kemih.

c. Metritis

Metritis adalah inspeksi uterus setelah persalinan yang 
merupakan salah satu penyebab terbesar kematian ibu. Bila pengobatan terlambat atau kurang adekuat dapat menjadi abses pelvic yang menahun, peritonitis, syok septik, trombosis yang dalam, embolipulmonal, infeksi felvik yang menahan dispareunia, penyumbatan tuba dan infertilitas.

d. Bendungan payudara

Bendungan payudara adalah peningkatan aliran vena dan limfe pada payudara dalam rangka mempersiapkan diri untuk laktasi. Bendungan terjadi akibat bendungan berlebihan pada limfatik dan vena sebelum laktasi. Payudara bengkak disebabkan karena menyusuiyang tidak kontinu, sehingga sisa ASI terkumpul pada daerah ductus. Hal ini dapat terjadi pada hari ke tiga setelah melahirkan. Penggunaan bra yang keras serta keadaan puting susu yang tidak bersih dapat menyebabkan sumbatan pada ductus.

e. Infeksi payudara

Mastitis termasuk salah satu infeksi payudara. Mastitis adalah peradangan pada payudara yang dapat disertai infeksi atau tidak, yang disebabkan oleh kuman terutama Sraphylococcus aureus melalui luka pada puting susu atau melalui peredaran darah.

f. Abses payudara

Abses payudara merupakan komplikasi akibat peradangan payudara/ mastitis yang sering timbul pada minggu ke dua postpartum (setelah melahirkan), karena adanya pembengkakan payudara akibat tidak menyusui dan lecet pada puting susu.

g. Abses pelvis

Penyakit ini merupakan komplikasi yang umum terjadi pada penyakit- penyakit meluar seksual (sexually transmitted 
disease/ STDs), utamanya yang disebabkan oleh chlamydia dan gonorrhea.

h. Peritonitis

Peritonitis adalah peradangan pada peritoneum yang merupakan pembungkus visera dalam rongga perut. Peritoneum adalah selaput tipis dan jernih yang membungkus organ perut dan dinding perut sebelah dalam.

i. Infeksi luka perineum dan luka abdominal

Luka perineum adalah luka perineum karena adanya robekanjalan lahir baik karena rupture maupun karena episiotomy pada waktu melahirkan janin. Rupture perineum adalah robekan yang terjadi padaperineum sewaktu persalinan.

j. Perdarahan pervagina

Perdarahan pervagina atau perdarahan postpartum adalah kehilangan darah sebanyak $500 \mathrm{cc}$ atau lebih dari traktus genetalia setelah melahirkan. Hemoragi postpartum primer mencakup semua kejadian perdarahan dalam 24 jam setelah kelahiran.

\section{a. Program Masa Nifas}

Paling sedikit 4 kali melakukan kunjungan pada masa nifas, dengan tujuan untuk:

i. Menilai kondisi kesehatan ibu dan bayi.

ii. Melakukan pencegahan terhadap kemungkinan kemungkinanadanya gangguan kesehatan ibu nifas dan bayi.

iii. Mendeteksi adanya komplikasi atau masalah yang terjadi pada masanifas.

iv. Menangani komplikasi atau masalah yang timbul dan 
mengganggu kesehatan ibu nifas maupun bayinya (Walyani, 2017).

Tabel 1. Program Masa Nifas (Walyani, 2017)

\begin{tabular}{|c|c|c|}
\hline $\begin{array}{l}\text { Kunjung } \\
\text { an }\end{array}$ & Waktu & Tujuan \\
\hline 1 & $\begin{array}{l}\text { 6- } 8 \text { jam } \\
\text { setelah } \\
\text { persalinan }\end{array}$ & $\begin{array}{l}\text { a. Mencegah terjadinya perdarahan } \\
\text { pada masanifas. } \\
\text { b. Mendeteksi dan merawat } \\
\text { penyebab lain perdarahan dan } \\
\text { memberikan rujukan bila } \\
\text { perdarahan berlanjut. } \\
\text { c. Memberikan konseling kepada } \\
\text { ibu atau salah satu anggota } \\
\text { keluarga mengenai bagaimana } \\
\text { mencegah perdarahan masa } \\
\text { nifas karena atonia uteri. } \\
\text { d. Pemberian ASI pada masa awal } \\
\text { menjadi ibu. ibu untuk } \\
\text { e. Mengajarkan antara } \\
\text { mempererat hubungan and } \\
\text { ibu dan bayi baru lahir. } \\
\text { f. Menjaga bayi tetap sehat } \\
\text { dengan cara mencegah } \\
\text { hipotermi. }\end{array}$ \\
\hline 2 & $\begin{array}{l}6 \text { hari } \\
\text { setelah } \\
\text { persalinan }\end{array}$ & $\begin{array}{l}\text { Memastikan involusi uteri berjalan } \\
\text { normal, uterus berkontraksi, } \\
\text { fundus di bawah }\end{array}$ \\
\hline
\end{tabular}




\begin{tabular}{|c|c|c|}
\hline & & $\begin{array}{l}\text { umbilicus tidak ada perdarahan } \\
\text { abnormal, dan tidak ada bau. } \\
\text { b. Menilai adanya } \\
\text { tanda- tanda demam, infeksi, } \\
\text { atau kelainan pasca melahirkan. } \\
\text { c. Memastikan ibu mendapat } \\
\text { cukup cairan, makanan, dan } \\
\text { istirahat. } \\
\text { d. Memastikan ibu menyusui } \\
\text { dengan baik dantidak ada tanda- } \\
\text { tanda penyulit. } \\
\text { e. Memberikan } \\
\text { kepada ibumengenai } \\
\text { asuhan pada bayi, cara merawat } \\
\text { tali pusat, dan menjaga bayi } \\
\text { agar tetaphangat. }\end{array}$ \\
\hline 3 & $\begin{array}{l}2 \text { minggu } \\
\text { setelah } \\
\text { persalinan }\end{array}$ & 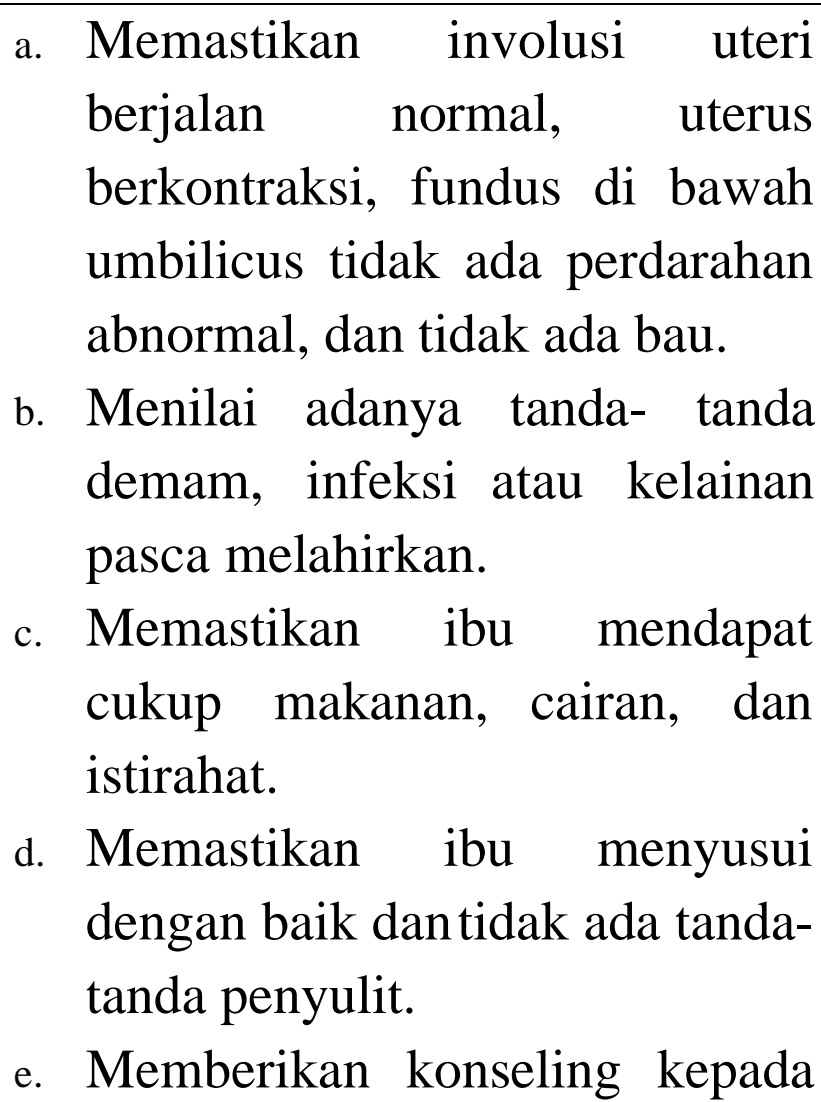 \\
\hline
\end{tabular}




\begin{tabular}{|c|c|c|}
\hline & & $\begin{array}{l}\text { ibu mengenai asuhan pada bayi, } \\
\text { cara merawat tali pusat, dan } \\
\text { menjaga bayi agar tetap } \\
\text { hangat. }\end{array}$ \\
\hline 4 & $\begin{array}{l}6 \text { minggu } \\
\text { setelah } \\
\text { persalinan }\end{array}$ & $\begin{array}{l}\text { a. Menanyakan pada ibu tentang } \\
\text { penyulit-penyulit yang dialami } \\
\text { atau bayinya. } \\
\text { b. Memberikan konseling untuk } \\
\text { KB secaradini. }\end{array}$ \\
\hline
\end{tabular}




\section{BAB VI \\ TEORI MANAJEMEN KEBIDANAN}

\section{A. Pengertian}

Manajemen adalah membuat pekerjaan selesai (getting thing done). Prinsip yang mendasari batasan ini adalah "komitmen pencapaian" yakni komitmen untuk melakukan kegiatan yang bertujuan, bukan semata-mata kegiatan. Manajemen adalah mengungkapkan apa yang hendak dikerjakan, kemudianmenyelesaikannya (Mufdlilah, 2009).

Manajemen kebidanan adalah pendekatan yang digunakan oleh bidan dalam penerapan metode pemecahan masalah secara sistematis mulai dari pengkajian, analisis data, diagnosa kebidanan, perencanaan, pelaksanaan dan evaluasi.

Menurut Varney (1997), proses penyelesaian masalah merupakan salah satu upaya yang digunakan dalam manajemen kebidanan. Varney berpendapat bahwa dalam melakukan manajemen kebidanan, bidan harus memiliki kemampuan berfikir secara kritis untuk menegakkan diagnosa atau masalah potensial kebidanan. Selain itu, diperlukan pula kemampuan kolaborasi atau kerja sama. Hal ini dapat digunakan sebagai dasar dalam perencanaan kebidanan selanjutnya, proses manajemen kebidanan diselesaikan melalui tujuh langkah, yaitu sebagai berikut: 


\section{1) Tahap pengumpulan data dasar (langkah I )}

Pada langkah pertama dikumpulkan semua informasi (data) yang akurat dan lengkap dari semua sumber yang berkaitan dengan kondisi klien. Untuk memperoleh data dilakukan dengan cara:

1) Anamnesis. Anamnesis dilakukan untuk mendapatkan biodata, riwayat menstruasi, riwayat kesehatan, riwayat kehamilan, persalinan dan nifas, bio- psiko-sosi-spritual, serta pengetahuan klien.

2) Pemeriksaan fisik sesuai dengan kebutuhan dan pemeriksaan tanda-tanda vital, meliputi:

a) Pemeriksaan khusus (inspeksi, palpasi, auskultasi dan perkusi)

b) Pemeriksaan penunjang (laboratorium dan catatan terbaru serta catatan sebelumnya)

Dalam manajemen kolaborasi, bila klien mengalami komplikasi yang perlu dikonsultasikan kepada dokter, bidan akan melakukan upaya konsultasi. Tahap ini merupakan langkah awal yang akan menentukan langkah berikutnya sehingga kelengkapan data sesuai kasus yang dihadapi akan menentukan tidak benarnya proses interprestasi pada tahap selanjutnya. Oleh karena itu, pendekatan ini harus komprehensif. Mencakup data subyektif, data obyektif, dan hasil 
pemeriksaan sehingga dapat mengambarkan kondisi pasien yang sebenarnya serta valid. Kaji ulang data yang sudah dikumpulkan apakah sudah tepat, lengkap dan akurat.

\section{2) Interprestasi Data Dasar(langkah II)}

Pada langkah kedua dilakukan identifikasi terhadap diagnosa atau masalah berdasarkan interprestasi yang benarbenar atas data-data yang telah dikumpulkan. Data dasar tersebut kemudian diinterpretasi sehingga dapat dirumuskan diagnosa dan masalah yang spesifik. Baik rumusan diagnosa atau masalah, keduanya harus ditangani. Meskipun, masalah tidak dapat ditarik sebagai diagnosis, tetapi tetap membutuhkan penanganan.

Masalah sering berkaitan dengan hal-hal yang sedang dialami wanita yang diidentifikasikan oleh bidan sesuai dengan hasil pengkajian. Masalah yang sering menyertai diagnosis.

Contoh:

Data: Ibu hamil 8 bulan, anak pertama, hasil pemeriksaan menunjukan tinggi fundus uteri $31 \mathrm{~cm}$, DJA (+), puki, presentasi kepala, penurunan 5/5, nafsu makan baik, penambahan berat badan selama hamil $8 \mathrm{~kg}$, ibu sering buang air kecil pada malam hari.

Diagnosa: $\mathrm{G}_{1} \mathrm{P}_{0} \mathrm{~A}_{0}$, hamil 32 minggu, preskep, janin 
tunggal hidup intra uterin, ibu mengalami gangguan fisiologis pada hamil tua.

Perasaan takut tidak termasuk katagori" nomenklatur standar diagnosis". Tetapi tentu akan menciptakan suatu masalah yang membutuhkan pengkajian lebih lanjut dan memerlukan suatu perencanaan untuk mengatasinya.

Diagnosa kebidanan merupakan diagnosa yang ditegakkan dan dalam lingkup praktik kebidanan dan mememuhi standar nomenklatur diagnosa kebidanan.

\section{3) Identifikasi Diagnosis/Masalah Potensial dan} AntisipasiPenanganannya (Langkah III)

Pada langkah ketiga kita mengidentifikasi masalah potensial atau diagnosis potensial berdasarkan diagnosa /masalah yang sudah diidentifikasikan. Langkah ini membutuhkan antisipasi, bila memungkinkan dilakukan pencegahan. Bidan diharapkan waspada dan bersiap-siap mencegah diagnosa/masalah potensial ini menjadi kenyataan. Langkah ini penting sekali dalam melakukan asuhan yang aman.

Pada langkah ini bidan dituntut untuk mengantisipasi masalah potensial tidak hanya merumuskan masalah potensial yang akan terjadi, tetapi juga merumuskan tindakan antisipasi agar masalah atau diagnosa tersebut tidak terjadi. Langkah ini bersifat antisipasi yang rasional/logis. 


\section{4) Menetapkan Perlunya Konsultasi dan Kolaborasi Segera dengan Tenaga Kesehatan Lain (Langkah IV)}

Bidan mengidentifikasikan perlunya bidan atau dokter melakukan konsultasi atau penanganan segera bersama anggota tim kesehatan lain sesuaidengan kondisi klien.

Langkah keempat mencerminkan proses kesinambugan proses manajemen kebidanan. Jadi, manajemen tidak hanya berlangsung selama asuhan primer periodik atau kunjungan prenatal saja, tetapi juga selama wanita tersebut dalam pendampingan bidan. Misalnya, pada waktu wanita tersebut dalampersalinan.

Dalam kondisi tertentu, seorang bidan juga perlu untuk berkonsultasi atau kolaborasi dengan dokter atau tim kesehatan lain seperti, pekerja sosial, ahli gizi atau seorang ahli perawatan klinis bayi baru lahir. Dalam hal ini, bidan harus mampu mengevaluasi kondisi setiap klien untuk menentukan kepada siapa sebaiknya konsultasi dan kolaborasi dilakukan.

Penjelasan di atas menunjukkan bahwa melakukan tindakan harus disesuaikan dengan prioritas masalah /kondisi keseluruhan yang dihadapi klien. Setelah bidan merumuskan hal-hal yang telah dilakukan untuk mengantisipasi diagnosa/masalah pada langkah sebelumnya bidan juga harus merumuskan tindakan darurat yang harus dilakukan untuk menyelamatkan ibu dan bayi. Rumusan ini mencakup 
tindakan segera yang bisa dilakukan secara mandiri, kolaborasi atau bersifat rujukan.

\section{5) Menyusun Rencana Asuhan Menyeluruh(Langkah V)}

Pada langkah kelima direncanakan asuhan menyeluruh yang ditentukan berdasarkan langkah-langkah sebelumnya. Langkah ini merupakan kelanjutan manajemen untuk masalah atau diagnosa yang telah diidentifikasi atau diantisipasi. Pada langkah ini informasi yang tidak lengkap dapat dilengkapi.

6) Pelaksanaan Langsung Asuhan dengan Efesien dan Aman(Langkah VI)

Pelaksanaan ini biasanya dilakukan oleh bidan atau sebagian dilakukan oleh klien atau anggota tim kesehatan lainya. Walaupun bidan tidak melakukannya sendiri, namun ia tetap bertanggung jawab untuk mengarahkan pelaksanaanya.

\section{7) Evaluasi(Langkah VII)}

Pada langkah keenam dilakukan evaluasi keefektifan asuhan yang sudah diberikan. Ini meliputi evaluasi pemenuhan kebutuhan:apakah benar-benar telah terpenuhi sebagaimana diidentifikasi dalam diagnosa atau masalah. Rencana tersebut dapat dianggap benar jika efektif melakukanya. 


\section{8) Manajemen kebidanan dengan metode SOAP}

Menurut Helen Varney(2009), alur berfikir bidan saat menghadapi klien meliputi 7 langkah. Untuk mengetahui apa yang telah dilakukan oleh seorang bidan melalui proses berfikir sistematis, didokumentasikan berbentuk SOAP, yaitu:

S (subjektif), Menggambarkan pendokumentasian hasil pengumpulan data klien melalui anamnesis sebagai Langkah Varney I.

$\mathrm{O}$ (objektif), menggambarkan pendokumentasian hasil pemeriksaan fisik klien, hasil laboratorium juga uji diagnostik lain yang dirumuskan dalam data fokus untuk mendukung sebagai asuhan Langkah Varney II

A (assessment), menggambarkan pendokumentasian tentang analisis dan interprestasi data subyektif dan obyektif dalam satu identifikasi:

1) Diagnosis/masalah

2) Antisipasi diagnosis/masalah potensial

3) Perlu tindakan segera oleh bidan atau dokter, konsultasi/ kolaborasi dan rujukan sebagai Langkah 2,3 dan 4 Varney.

$\mathrm{P}$ (plan), menggambarkan pendokumentasian dan tindakan (I) dan evaluasi perencanaan (E) berdasarkan assessment sebagai Langkah 5,6 dan 7 Varney. 


\section{9) Teori Hukum Kewenangan Bidan}

Dengan berjalannya waktu kewenangan bidan di Indonesia dari tahun ke tahun selalu berkembang. Kewenangan bidan yang sesuai dengan permenkes RI No.1464/2010, tentang perizin dan penyelengaraan praktik bidan mandiri dalam melakukan asuhan kebidanan meliputi:

1. Peraturan Menteri Kesehatan menurut Permenkes RI No.1464/2010 ( BAB III ), tentang perizin dan penyelengaraan praktik bidan mandiri yaitu:

a. Pada pasal 2, yang berbunyi:

1) Bidan dapat melakukan praktik mandiri dan atau bekerja di fasilitaspelayanan kesehatan.

2) Bidan yang menjalankan praktik mandiri harus berpendidikan minimalDiploma III Kebidanan.

3) Bidan yang menjalankan praktik harus mempunyai SIPB. Analisa :

Pada ayat di atas dapat dianalisa bahwa bidan yang akan menyelengarakan praktik bidan mandiri harus berpendidikan minimal Dilpoma III Kebidanan dan mempunyai SIPB

b. Pada pasal 9, yang berbunyi:

Bidan dalam menjalankan praktik, berwenang untuk memberikan pelayananyang meliputi: 
1) Pelayanan kesehatan ibu.

2) Pelayanan kesehatan anak; dan

3) Pelayanan kesehatan reproduksi perempuan dan keluarga berencana.

c. Pada pasal 10, yang berbunyi:

1) Pelayanan kesehatan kepada ibu sebagaimana dimaksud dalam pasal 9 huruf a diberikan pada masa pra hamil, masa persalinan, masa nifas, masa menyusui dan masa antara dua kehamilan

2) Pelayanan kesehatan ibu sebagaimana yang dimaksud pada ayat(1) meliputi:

a) Pelayanan konseling pada pra hamil

b) Pelayanan antenatal pada kehamilan normal

c) Pelayanan persalinan normal

d) Pelayanan ibu nifas normal

e) Pelayanan ibu menyusui; dan

f) Pelayanan konseling pada masa antara dua kehamilan

3) Bidan dalam memberikan pelayanan sebagaimana yang dimaksud ayat (2) berwenang untuk:

a) Episiotomi

b) Penjahitan luka jalan lahir tingkat I dan II 
c) Penanganan kegawat - daruratan, dilanjutkan dengan perujukan

d) Pemberian tablet Fe pada ibu hamil

e) Pemberian vitamin A dosis tinggi pada ibu nifas

f) Fasilitas / bimbingan inisiasi menyusu dini dan promosi air susu ibueksklusif

g) Pemberian uterotonika pada manajemen aktif kala tiga dan postpartum

h) Penyuluhan dan konseling

i) Bimbingan pada kelompok ibu hamil

j) Pemberian surat keterangan kematian; dan

k) Pemberian surat keterangan cuti bersalin

d. Pada pasal 18, yang berbunyi:

Bidan dapat memberikan pelayanan sebagaimana yang dimaksut dalam pasal 16 berwenang untuk:

a) Memberikan imunisasi

b) Memberikan suntikan pada penyulit kehamilan, persalinandan nifas

c) Mengeluarkan plasenta secara manual

d) Bimbingan senam hamil

e) Pengeluaran sisa jaringan konsepsi 


\section{BAB VII \\ CONTOH SOAL}

1. Seorang Perempuan, umur 27 tahun, telah melahirkan 30 menit yang lalu, hasil pemantauan TD : 110/90 mmHg, $\mathrm{N}$ : $20 \mathrm{x} / \mathrm{menit}, \mathrm{P}$ : $18 \mathrm{x} /$ menit, $\mathrm{S}: 37$ 0C, TFU setinggi pusat, perdarahan $30 \mathrm{CC}$. Apakah Panggilan yang tepat untuk ibu tersebut?

a. Ibu Primi Para

b. Ibu Post Partum

c. Ibu Multi Para

d. Ibu Grande Multipara

2. Seorang Perempuan Usia 30 Tahun telah melahirkan pada Pukul 21.00 Wita tanggal 1 November 2021 dan dilakukan pengkajian pada tanggal 7 November 2021. Maka perempuan tersebut berada pada peroide?
a. Early puerperium
b. Immediate puerperium
c. Late puerperium
d. Post puerperium

3. Seorang Perempuaan, usia 30 tahun telah melahirkan 7 hari yang lalu, hasil pemanatauan TD : 110/90 $\mathrm{mmHg}, \mathrm{N}: 20 \mathrm{x} / \mathrm{menit}, \mathrm{P}: 18$ $\mathrm{x} /$ menit, $\mathrm{S}: 37$ 0C, TFU setengah pusat simpisis, Lockhea mengandung sedikit darah \& lebih banyak serum serta mengandung leukosit \& robekan/laserasi plasenta. Hasil Pemeriksaan Lockhea tersebut adalah?

a. Lockhea Rubra

b. Lockhea Sanguinolenta

c. Lockhea Serosa

d. Lockhea Alba

4. Seorang Perempuan Usia 17 Tahun telah melahirkan anak pertama di PKM Kassi - Kassi Pada Pukul 09. 00 Wita. Hasil pemeriksaan 
TD : 90/60 mmHg, N : 18 x/menit, P : 16 x/menit, S : 37 0C, TFU Setinggi Pusat, Perdarahan 30 CC. Secara Psikologis Ibu tersebut akan melewati Fase?

\section{a. Phase honeymoon - Phase taking inn - Phase taking hold - Phase letting go}

b. Phase taking inn - Phase honeymoon - Phase taking hold - Phase letting go

c. Phase letting go - Phase taking inn - Phase honeymoon - Phase taking hold

d. Phase honeymoon - Phase taking hold - Phase letting go - Phase taking inn

5. Seorang Perempuan Usia 31 Tahun telah melahirkan anak pertama 2 hari yang lalu di PKM Kassi - Kassi Pada Pukul 11. 00 Wita. Hasil pemeriksaan TD : 110/60 mmHg, $\mathrm{N}: 20 \mathrm{x} /$ menit, $\mathrm{P}: 18$ $\mathrm{x} /$ menit, $\mathrm{S}: 37,2$ 0C, TFU 2 jari bawah Pusat, Pada saat ini ibu merasa pasif pada lingkungannya, ibu lebih perhatian terhadap dirinya dibanding kebayinya dan juga ibu tidak menginginkana kontak dengan bayinya. Maka pada saat ibu ibu berada pada Fase?
a.Phase taking inn
b. Phase honeymoon
c. Phase taking hold
d. Phase letting go

6. Seorang Perempuan Usia 30 Tahun telah melahirkan anak pertama 10 hari yang lalu di PKM Kassi - Kassi. Hasil pemeriksaan TD : 110/90 mmHg, N : 20 x/menit, P : 18 x/menit, S : 37,2 0C, TFU tidak teraba. Pada saat ini ibu berada pada fase Letting Go. Beriku Peran bidan dalam menangani fase ini Kecuali ?

a. Jaga hubungan keluarga yang harmonis

b. Dukungan keluarga untuk membantu pasien dam menemaninya beberapa hari

c. Biarkan bayi bersama ibunya

d. Biarkan ibu memiliki waktu untuk dirinya sendiri. s 
7. Seorang Perempuan Usia 34 Tahun telah melahirkan anak pertama di PKM Kassi - Kassi. Hasil pemeriksaan TD : 120/90 mmHg, N : $20 \mathrm{x} /$ menit, $\mathrm{P}: 20 \mathrm{x} /$ menit, $\mathrm{S}: 37,0$ 0C, TFU tidak teraba. Pada saat ini ibu mengalami kemurungan yang diakibatkan oleh Perubahan hormonal yang terjadi pada tubuh ibu, Masa transisi, Ketidakstabilan emosi ibu nifas, Ketidaknyamanan fisik, Perubahan dalam irama kehidupan ibu. Perubahan ini disebut?
a. Kesedihan Dan Berduka Cita
b. Post Partum Blues
c. Depresi Post Partum
d. Psikosa Post Parum

8. Seorang Perempuan Usia 34 Tahun mengalami kematian janin dalam Rahim di PKM Kassi - Kassi. Hasil pemeriksaan TD : 120/90 mmHg, N : 20 x/menit, P : 20 x/menit, S : 37,0 0C, TFU tidak teraba. Pada saat ini ibu akan melalui proses yang disebut?

a. Syok dan menyangkal - Disorientasi dan depresi - Reorganisasi dan penerimaan - Marah dan bargaining

b. Syok dan menyangkal - Marah dan bargaining - Disorientasi dan depresi - Reorganisasi dan penerimaan

c. Disorientasi dan depresi - Reorganisasi dan penerimaan - Syok dan menyangkal - Marah dan bargaining

d. Reorganisasi dan penerimaan - Syok dan menyangkal Disorientasi dan depresi - Marah dan bargaining

9. Seorang Perempuan Usia 30 Tahun telah melahirkan 1 jam yang lalu di PKM Kassi - Kassi. Hasil pemeriksaan TD : 110/90 mmHg, $\mathrm{N}$ : $20 \mathrm{x} /$ menit, $\mathrm{P}: 18 \mathrm{x} /$ menit, $\mathrm{S}: 37,2$ 0C, TFU Lembek, Perdarahan $30 \mathrm{cc}$. untuk melakukan pemantauan makan bidan hendaknya melakukan observasi pada?
a. Vulva
b. Kandung Kemih
c. Perineum 


\section{d. Laserasi}

10. Seorang Perempuan Usia 30 Tahun telah melahirkan 1 jam yang lalu di PKM Kassi - Kassi. Bidan senior yang bertugas pada ruang nifas meminta untuk bidan junior melakukan pemantauan maka pemantauan yang harus dilakukan adalah ?
a. TTV - Urine - Perdarahan
b. TTV - TD - Pernafasan - Suhu
c. TTV - Laserasi - Perdarahan
d. TTV - Urine - Pernafasan 


\section{KUNCI JAWABAN}

1. B

2. A

3. $\mathrm{C}$

4. A

5. A

6. D

7. $B$

8. B

9. B

10. A 


\section{DAFTAR PUSTAKA}

Andreasz George At All, Buku Acuhan Pelayanan Neonatal

Kesehatan Maternal, Cetakan Ke II, tahun 2002

Andreasz George At All, Buku Acuhan Pelayanan Neonatal

Kesehatan Maternal, Cetakan Ke I, tahun 2001

Bobak at all, Maternity Nursing, Fourth edition, mosby, tahun

1991 Bennett Brown, Myles Midwifery text book for midwives, 2003

Buku Panduan Praktis Pelayanan Kesehatan Maternal Dan Neonatal, Yayasan Bina Pustaka Sawono Prawihardjo,Jakarta 2002

Miller Hanretty, Obstetrics Illustrated, Fitih Edition, Churchill Livingstone, 1997

JNPK, Persalinan Normal Buku Acuhan Akbid, tahun 2002 Sarwono Prawiharjo, Buku Ilmu Kebidanan, Cetakan Ke IV,

Jakarta, tahun 1997

Seller, Paulin, Midwifery Volume I,Juta\& Co.Ltd,tahun 1993 Seller, paulin, Midwifery Volume II,Juta\&

Co.Ltd,tahun 1993Verney, Buku Acuhan Manajemen

Kebidanan, tahun 1997 William Obstetric, Edisi 18, EGC,2000

Sara Wickham, Midwifery Best Practice,tahun 2003

Bidan dan dosen kebidanan Indonesia, Kebidanan Teori Dan Asuhan Volume 1,tahun 2018

Bidan dan dosen kebidanan Indonesia, Kebidanan Teori DanAsuhan Volume I1,tahun 2018 
Caroline Squire, The Social Context Of Birth, tahun 2017

Asih Y \& Risneni. 2016. Buku Ajar Asuhan Kebidanan Nifas dan Menyusui dilengkapi dengan Evidence Based Practice danDaftar Tilik Asuhan Nifas. TIM: Jakarta .Bidan dan Dosen Kebidanan Indonesia.2017. Kebidanan Teori dan Asuhan Volume 1. EGC: Jakarta

Bidan dan Dosen Kebidanan Indonesia.2017. Kebidanan

Teori danAsuhan Volume 2. EGC: Jakarta

Hernawati E \& Kamila L. 2017. Buku Ajar

KegawatdaruratanMaternal \&Neonatal. TIM:

Jakarta

JNPK-KR. 2014. Asuhan Persalinan Normal Asuhan Esensial Bagi Ibu Bersalin dan Bayi Baru Lahir Serta Penatalaksanaannya Komplikasi segera Pasca Persalinan dan Nifas

KEMENKES. 2014.Buku ajar kesehatan ibu dan anak.

GAVI:Jakarta Selatan

KEMENKES. 2014.Buku Ajar Imunisasi. GAVI: Jakarta Selatan Maritalia D. 2014. Asuhan Kebidanan Nifasdan Menyusui. Pustaka Belajar: Yogyakarta

Rismalinda, P.H. 2014. Dokumentasi Kebidanan.In Media: Jakarta Tando M.N. 2016. Asuhan Kebidanan Neonatus, bayi dan anak Balita. EGC: Jakarta 


\section{Biografi Penulis}

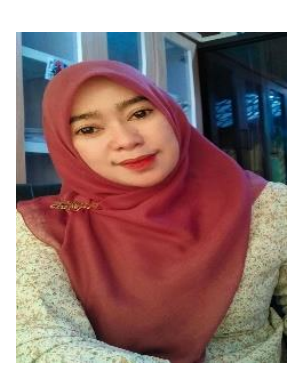

Sumarni, S.ST., M.Keb Lahir Makassar pada tanggal 17 Maret 1987. Penulis merupakan salah satu dosen Tetap Universitas Megarezky pada program Studi DIII Kebidanan yang telah menyelesaikan Magister kebidanan di Universitas Hasanuddin pada tahun 2017. Pada tahun 2020 penulis meraih hibah penelitian dari Kementrian Riset dan Teknologi Badan Riset dan Inovasi Nasional. Dengan Latar belakang ilmu kebidanan penulis telah menerbitkan 3 buah buku, dimana pada kesempatan ini buku ASUHAN KEBIDANAN PADA MASA NIFAS merupakan buku acuan mahasiswa dalam memberikan layanan kebidanan ke ibu nifas.

\section{Biografi Penulis}

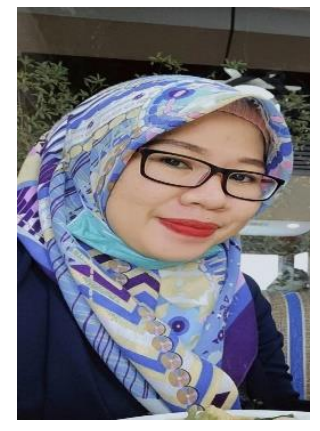

Nahira, S.ST., M.Keb Lahir di Makassar, pada tanggal 23 Agustus 1989. Penulis anak bungsu dari 2 bersaudara oleh seorang ayah $\mathrm{H}$. Kandari Iskandar dan Ibu Hj. Hamsiah. Menempuh pendidikan DIII Kebidanan di Akbid Muhammadiyah Makassar, dan lulus pada tahun 2011, melanjutkan jenjang pendidikan D. IV Bidan Pendidik di STIKes Mega Rezky Makassar tahun 2013, dan meraih gelar Magister Kebidanan di Universitas Hasanuddin pada tahun 2017. Penulis pernah bekerja sebagai bidan desa di Puskesmas Bentang Kecamatan Galesong Kabupaten Takalar pada tahun 2013, dan menjadi dosen tetap pada program studi D.IV Kebidanan Universitas Megarezky sejak tahun 2016 sampai saat ini. Tahun 2020 penulis meraih Hibah Penelitian dari Kementerian Riset dan Tekhnologi Badan Riset dan Inovasi Nasional. 